\title{
A REVIEW OF THE AMERICAN SPECIES OF TETRAODONTIDI.
}

\section{By DAVIDS. JORDAN and CHARUIES L. EDWATES.}

In the present paper we have attempted to review the synonymy of the American species of Puffers or Tetraodontida, and to give analytical keys by which the genera and species may be distinguished. The specimens examined have been chiefly collected by Professors Jordan and Gilbert. These are in the museum of the Indiana University, while duplicate series are in the U.S. National Museum.

We accept the family of Tetraodontida as including all the Plectognathous fishes, in which the teeth in each jaw are coalesced into a bony plate, which in each jaw is divided by a median suture. The American species of this group, all referred by Dr. Giinther to the single genus Tetrodon, fall into five groups which are certainly natural and apparently well-defined, and which we regard as distinct genera.

These may be defined as follows:*

a. Frontal bones articulated with the supraoccipital and the postfrontals confined to the sides, the ethmoid little prominent to view above and short or narrow ; back not carinated; snout heavy and broad; vertebræ in moderate or small number ( 7 to $8+9$ to 13 ); dorsal and anal fins each with 6 to 15 rays; skin smooth or more or less prickly, without scutes (Tetrodontine).

b. Frontal bones expanded sidewise and forming the lateral roofs of the orbits, the postfrontals limited to the posterior portions. Marine species.

c. Nostril, on each side, with two distinct openings; frontal region longer than broad.

d. Dorsal and anal fins comparatively long, falcate, each of 12 to 15 rays; caudal lunate; vertebræ about 20 ; nostrils sessile or nearly so, not forming a distinct papilla; mucous tubes on upper part of head and on sides of body very conspicuous .............................

dd. Dorsal and anal fins comparatively short, rounded, each of 6 to 8 rays; caudal usually rounded; vertebræ about $8+10$; nostrils at the summit of a hollow, simple (or lobed) papilla; mucous tubes inconspicuous.

SPHEROIDES, 2.

cc. Nostril on each side, with a bifid tentacle, without distinct opening; frontal region broader than long; fins and vertebræ as in Spharoides.

TETraOdon, 3.

bb. Frontal bones narrowed and excluded from the orbit, the postfrontals being elongated and projected forwards and connected with the prefrontals; dorsal and anal fins short, rounded; snout very obtuse ; vertebræ $8+11$; nostrils (probably) as in Spharoides. Fluviatile species.

Colomesus, 4 .

*The osteological characters here given are mostly copied from Professor Gill's "Synopsis of the Plectognath Fishes" (Proc. U.S. Nat. Mus., 1884, 411), and weru by him derived chiefly from the plates in Hollard's "Études sur les Gymnodontes" (Ann. des Sciences Naturelles, Paris, 1857, viii). 
$a a$. Frontal bones separated from the supraoccipital by the intervention of the postfrontals, which are connected together and laterally expanded but short, the ethmoid prominent above, enlarged and narrowed forwards; nostrils obsolete, imperforate; head compressed, the snout slender and produced; back compressed to a sharp edge or keel; dorsal and anal fins short and rounded (rays 5 to 8 ); vertebræ $8+9$; skin smooth or prickly, without seutes (Canthigasterina) ........... CANTHIGASTER, 5.

\section{I.-LAGOCEPHALUS.}

TETraOdon species, Linnæus and of early authors (not type, as later restricted).

Lagocephalus Swainson, Nat. Hist. and Class'n Fishes, ii, 194, 328, 1839 (stellatus ; pennanti=lagocephalus $\mathrm{L}$.).

Physogaster Müller, Abhandl. Akad. Wiss., Berlin, 1839 (1841), 252 (lunaris ; oblongus); (name preoccupied).

Gastrophysus Müiller, Wiegmann's Archiv. ix, 330, 1843 (lunaris).

Les Promécocephales (Promecocephalus) Bibron, MSS., Révue de Zoologie, 1855, 279

(argentatus; lunaris ; spadiceus ; levigatus ; lagocephalus ("Bloch, nec L."); inermis). Gastrophysus Bleeker, Nat. Tydskr. Ned. Ind., \&c., about 1855.

Tetrodon Gill, Cat. Fish. East. Coast N. Am., 1873, 15 (lavigatus, \&c.).

Lagocephalue Jordan \& Gilbert, Syn. Fish. N. A., 1883, 859 (levigatus, \&c.).

Type Tetrodon lagocephalus Linnæus.

This genus is close to Sphceroides in all technical respects, but it seems to be sufficiently distinguished by its nostrils and the form and development of its fins. This increase in the number of fin-rays marks a slight step in the direction of the genus Xenopterus (Chonerhinus). The species reach a larger size than do those of our other genera, and the body is more elongate in form. This is the only genus which is represented in the fauna of Europe.

The name of this genus offers no difficulty, Lagocephalus being prior to Gastrophysus, while Physogaster, which has nearly the same date as Lagocephalus, is preoccupied. The characters assigned by Swainson to Lagocephalus are valueless, but the indicated types belong to this group. Only one American species is certainly referred to Lagocephalus. A second one has been dcubtfully noted as occurring in Brazil.*

ANALYSIS OF SPECIES OF LAGOCEPHALUS.

a. Belly covered with large, subequal, three-rooted spines, the body otherwise smooth. Dorsal rays 14; anal rays 12 . Interobital space flat, shorter than snout, $1 \frac{1}{2}$ times diameter of eye; body elongate, its depth $4 \frac{1}{2}$ in length; tail slender, a ridge of skin on its lower edge on each side. Olive-green above, sides and below lustrous silver-white................................

* Dr. Günther mentious a specimen from Brazil, which he refers to a variety of Lagocephalus lunaris (Bloch \& Schneider), a species otherwise only known from the East Iudian fauna. This specimen is described as having the interorbital space and neck covered with spines (like the belly), the length of the head equal to its distance from the dorsal fin, aud a broad dark band across the middle of the back. 


\section{Lagocephalus lævigatus.*}

Ostracion cathetoplateo oblongus Artedi, genera 58, species No. 13, 1738 (after Orbis lagocephalus Grew, \&c.).

Tetrodon levigatus Linnæus, Syst. Nat., ed. xii, 411, 1766 (on a specimen collected at Charleston by Dr. Garden); Schöpf, Schrift. Naturf. Freunde, 1788, 189 (Rhode Island); Gmelin, Syst. Nat., 1447, 1788 (copied); Walbaum, Artedi Piscium, 595, 1792 (copied); Bloch \& Schneider, Syst. Ichthyol., 1801, 506 (copied); Turton, Syst. Nat., 1806, 891 (copied); Günther, Cat. Fish. Brit. Mus., viii, 18ז0, 274 (Bahia; Gulf of Mexico); Gill, Cat. Fish. E. Coast N. Am., 1873, 15 (name only); Poey, Enum. Piscium Cuben., 171, 1875 (Cuba); De Kay, N. Y. Fauna, Fishes, 329, 1842 (New York); Storer, Hist. Fish. Mass., 2:4, 1857 (Nantucket); Baird, U. S. Fish. Com., 1871-'72, 823 (Wood's Holl); Poey, Syn. Piscium Cubensis, 431, 1868 (Cuba).

Apsicephalus (Promeçocephalus) larigatus Hollard, Etudes sur les Gymnodontes, 1857 (figures of skulls).

Gastrophysus lavigatus Bleeker, "Natuurh. Verh. Holl. Maatsch. Wet. Haarlem, 1863, xviii, 22."

Lagocephalus lavigatus Jordan \& Gilbert, Proc. U. S. Nat. Mus., 1878, 367 (Beaufort, N. C.); Goode, Proc. U. S. Nat. Mus., 1879, 109, (St. John's River, Florida); Goode \& Bean, Proc. U. S. Nat. Mus., 1879, 122 (Pensacola, Fla.); Jordan \& Gilbert, Proc. U. S. Nat. Mus., 1882, 305 (Galveston); Jordan \& Gilbert, l. c., 1882, 619 (Charleston); Jordan \& Gilbert, Synopsis Fish. N. A., 1883, 860 ;Jordan, Cat. Fish. N. Am., 141, 1885.

Tetrodon lagocephalus Bloch, Ausl. Fische, 1, 126, taf. 140; Bloch \& Schneider, Syst. Ichth., 1801, 503 (not of Linnæus).

Tamboril Parra, Dif. Piezas de Hist. Nat., 1787, 37, lam. 10 (Havana).

Le Tetrodon Mal-Armé Lacépède, Hist. Nat. Poiss., i, 497, 1798 (copied).

Tetrodon curvus Mitchill, Trans. Lit. \& Phil. Soc., i, 472, 1815 (New York; young); De Kas, N. Y. Fauna, Fishes; 1842, 328 (copied).

Tetrodon mathematicus Mitchill, Trans. Lit. \& Phil. Soc., i, 474, 1815 (New York). Tetrodon pachycephalus Ranzani, Nov. Comm. Ac. Sci. Inst. Bonon., iv, 1840, 73, pl. 11, f. 2 (Brazil).

Holacanthus melanothos Gronow, Systema, ed. Gray, 1854, 24; (based on T. lavigatus of Linnæus).

Tetrodon lineolatus Poey, Synops. Piscium Cuben., 432, 1868 (Cuba); Poey, Enum. Piscium Cuben., 172, 1875 (Cuba; Young).

Habitat.-Tropical and temperate shores of Atlantic coast of America; Cape Cod to Brazil.

The synonymy of this common species offers no difficulty. First described under the specific name of lavigatus, it has been known by the same name by nearly all authors subsequent to Linnæus.

\section{II.-SPHÆROIDES.}

Tetraodon species Linnæus, Systema Naturæ, ed. x, 1758, 332 (several species: testudineus rnentioned first).

Les Spharoides Lacépède, Hist. Nat. Poiss., ii, 1, 1798 (French name only).

Spharoides Lacépède, Pillot edition, Hist. Nat. Poiss., vi, 279, 1831 (tuberculatus= spengleri).

Cirrhisomus Swainson, Nat. Hist. Class'n Fishes, ii, 1839, 194, 328 (spengleri).

* Macleay, Cat. Austr. Fish., ii, 273, 1881, records this species from Port Jackson, Australia. This breadth of range needs verification. 
Cheilichthys Müller, Abhandl. Akad. Wiss. Berlin, 1839 (1841 ?), 252 (testudineus?).

Holacanthus species, Gronow, Systema Ed. Gray, 1854, 23 (includes all Tetrodontidee and Diodontida). (Name preoccupied.)

ANCHisomus Kaup MSS., Richardson, Voyage Herald, 1854, 156 (geometricus = testudineus, etc.).

Les Stenometopes (STENometopus) Bibron 1. c. (testudineus, spengleri, plumieri, marmoratus, angusticeps (no diagnosis).

Les Amblirhynchotes (AMbly Rhynchotus) Bibron, 1. e. (honckeni, oblongus, richei).

? Les Aphanacanthes (Aphanacanthus) Bibron, Revue de Zoölogie, 1855, 279 (reticulatus Bibron MSS. No diagnosis).

? Les Epipedorhynches (EPIPEDORHYNCHUS) Bibron, 1. c. (freycineti, etc., MSS. species. No diagnosis).

? Les Geneions (GENEION) Bibron, 1. c. (maculatum Bibron MSS.).

? Les Cataphorhynques (CATAPHORHynchus) Bibron, 1. c. (lampris, longispinis Bibron MSS.).

Apsicephalus Hollard, Etudes sur les Gymnodontes 1867, 324 (as sulstitute for and including the foregoing names of Bibron and Promecocephalus also, the type specified being a Dilobomycter).

? Lrosaccus Günther, Cat. Fish., Brit. Mus., viii, 1870, 287 (cutaneus).

Tetrodon Jordan \& Gilbert, Syn. Fish., N. A. 859, 1883 (testudineus).

Cirrhisomus Gill, Proc. U. S. Nat. Mus., 1884, 421 (spengleri).

\section{Type Tetrodon spengleri Bloch.}

The reasons for using the name Tetraodon for Miiller's Arothron instead of the present group are given farther on, under the head of Tetraodon.

If, as we suppose, Tetraodon is not available as the name of the present group, the name Sphceroides seems to us to have the clear right of priority. In the first volume and the first half of the second volume of his Histoire Naturelle des Poissons, Lacépède uses French names only, and it is in this part of his work that his "Sphéroide tuberculé," the type of his genus, "les Sphéroides," occurs. This name should then be passed over. Among the several reprints of Lacépède's work, there is, however, one now before me, in which the name of "Pillot" appears on the title page as "Editeur." In this edition (volume 6, published in 1831) Latin names are given to all"the species, and the Latin form "Sphceroides tuberculatus" is here applied. The name Sphceroides dating, then, from 1831, has clear priority over Cirrkisomus of Swainson (1839) and Cheilichthys of Müller (1S41). The name is also preferable to either of these in other respects. Lacépède's diagnosis is, of course, worthless, as the genus is based on a front view of a species (tuberculatus=spengleri) of which he had referred a side view to the genus Tetrodon. Most of the species of Sphcroides are American, as those of Tetraodon are chiefly East Indian. The species reach in general a much smaller size than those of Lagocephalus.

In all our species the nasal openings are comparatively large and placed at the summit of a simple hollow papilla. In some East Indian species, probably referable to this genus, this nasal papilla is two-lobed, a nasal opening in each lobe. 


\section{ANALYSIS OF SPECIES OF SPHEROIDES.}

a. Caudal fin lunate or truncate, with the angles notably produced.

$b$. [Body everywhere perfectly smooth; interorbital space broad, about equal to length of snout and twice diameter of eye; caudal truncate, its angles produced. Dorsal rays 10 . Light brown, with darker

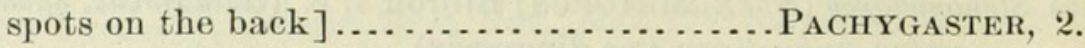

$b b$. Body more or less prickly, both above and below; the spines above slender; profile steep; a dark spot or band at base of pectoral.

c. [Color brownish above, faintly vermiculated with paler, sides yellowish; spines on the head long, close-set, like seals' bristles; dorsal region from a little behind nares to above ends of pectoral fins spinons; belly spinous; interorbital width $1 \frac{1}{4}$ in eye (in specimen 4 inches long); caudal fin truncate, or slightly concave, with prominent angles, D. 8, A. 7; eye $3 \frac{1}{2}$ in head] ....... TrichocephaLes, 3.

oc. Color brownish above, with small irregular bluish-gray spots; sometimes three faint blackish cross-bands, the foremost on the forehead, the others on the back before the dorsal; numerous fine sharp spines on the upper side of the body, from the nostrils to the base of the dorsal, and below from the throat to the vent; a slight fold along each side of the tail; caudal fin weakly concave; eye 4 in head, abont equal to the interorbital wilth. D. 8, A. 7 . FürTHI, 4.

aa. Candal fin rounded or subtruncate, the middle rays longest (rarely the uppermost very slightly produced).

d. Nape with a pair of fleshy flaps; interorbital area very narrow, deeply concave, channel-like, not broader than the eye; sides with small fleshy cirri; belly and anterior part of back with slender, tworooted prickles; body comparatively elongate, the snout produced, a little longer than the rest of the head; caudal rounded; dorsal rays 7; color smoky gray, sides yellowish-brown, covered with innumerable small spots of a sky-blue color, each with a sharply defined black edge; a row of obseure large blackish cross-blotches along lower part of sides from snout to caudal peduncle (as in S. spengleri); a black streak on base

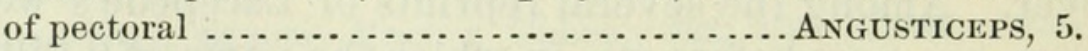

$d d$. Nape without dermal flaps; interorbital space broader, flattish or some what concave; snout about as long as rest of head.

$e$. Interorbital space rather narrow, somewhat concave, its width less than half the length of the snout; sides with a series of about 12 black blotches or bars bounding the pale color of the abdomen; back without curved cross-streaks or circles; upper ray of caudal slightly produced.

$f$. Sides of head and body always smooth, except sometimes a strip behind pectorals; spines larger, higher, more distinctly stellate and much less closely set than in C. turgidus, sometimes confined to the belly or the nuchal region, and often, especially in old specimens, wanting altogether, so that the skin is perfectly smooth; sides often with small whitish fleshy flaps or cirri, especially in the young. Color greenish or grayish, with fine bluish spots and vermiculations. Black blotches on lower part of sides nearly round; caudal fin with a broad dusky bar at base and tip, the middle pale .............. SPENGLERI, 6 . 
$f f$. Sides of head and body always prickly; as is the back from upper lip to base of dorsal; belly prickly from lower lip to vent; prickles all similar, small, mostly 3 -rooted, stiff and close set, rather largest posteriorly on back and belly, never obsolete; sides without cirri ; color dark olivaceous above, somewhat marbled and dotted with black; black blotehes on lower part of sides in the form of short cross-bars, somewhat oblique, the one nearest behind pectoral most conspicuous; caudal fin plain or nearly so, the tip darker................................

$e e$. Interorbital space rather broad and flattish, its width more than half length of snout; sides with no distinct series of dark blotches bounding the white of the belly; back and sides with numerous irregular round black spots and usually with curved crossstreaks, often appearing as arcs of concentric circles.

g. Skm of back and sides perfectly smooth; skin of belly smooth or with a few prickles embedded in folds of the skin. Color brown, with very numerous small round dark spots above; usually pale curved cross-bars present, in the form of concentric rings, one on middle of back in front of dorsal, another surrounding this, the remainder appearing as bars, anteriorly running downwards and backwards, posteriorly downwards and forwards. No cirri. (Adult form of $S$. testudineus?) ........... Politus, 8.

gg. Skin of back from nape to before dorsal fin covered with small, sparsely-set prichles; belly from throat to before anal with prickles which are rather larger and.more elosely set; axil usually prickly; sides sometimes with cirri.

$h$. Curved lines and streaks on the back whitish, paler than the ground color; usually arranged as follows: a circle or rhomb on the middle of the back before the dorsal fin; an ellipse surrounding this; before this three or four cross-streaks extending downward and backward, the one at the nape and the one behind the eyes connected on the median line; back and sides with many irregular round blackish spots of different sizes; a dark bar at base of pectoral, caudal dusky at base, then pale, the posterior half blackish ................ Testudineus, 9 .

$i$. Snout rather short, the eye nearer the end of the snout than the gill-opening .............................. Annulatus 9 (a).

ii. Snout rather longer, the eye nearer the gill-opening than the end of the snout............................. Testudineus $9(b)$.

hh. Curved lines, streaks, and circles on the back black, darker than the ground color; snout rather short, the eye being nearer end of snout than gill-openings; in all other respects essentially as

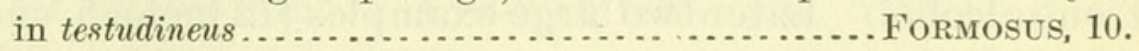

\section{Sphæroides pachygaster.}

Tetrodon (Cheilichthys) pachygaster Müller \& Troschel in "Schomburgk's Hist. Barbadoes, about 1840,677." (Barbadoes.)

Tetrodon pachygaster Günther, VIII, 287, 1870. (Copied.)

Habitat.-West Indian fauna. "A scarce species around Barbadoes." This species is known to us only from the brief diagnosis copied by Günther from Mïller \& Troschel.

It is probably the adult form (length 14 inches) of some species which is prickly when young. It may be the same as S.trichocephalus, or possibly an old example of $S$. testudineus. The latter is not known, however, to have the angles of the caudal produced even in old examples. 
3. Sphæroides trichocephalus.

Tetrodon trichocephalus Cope, Proc. Ac. Nat. Sci. Phila., 1870,120 (Newport, R. I.); Jordan \& Gilbert, Synopsis Fish. N. A., 188:3, 862 (copied); Jordan, Cat. Fish. N. Am., 1885, 441 (name only).

\section{Habitat.-West Indian fauna; Gulf Stream.}

This species is known to us only from Cope's description of a small specimen taken in the Gulf Stream off Newport. It is apparently very close to $S$. fürthi, and it is not unlikely that it will prove to be the young S. pachygaster; but as the latter species is known only from a poor description of a single specimen, it is not possible to form any positive opinion.

\section{Sphæroides fürthi.}

Tetrodon fürthi Steindachner, Ichthyol. Beitr. v. 22, $18 \pi 4$ (Panama); Jordan, Proc. U. S. Nat. Mus., 1885, 393 (Panama).

\section{Habitat.-Panama fauna.}

Specimens of this species, agreeing well with Dr. Steindachner's description, were obtained by Professor Gilbert at Panama in 1883. These specimens have been destroyed by fire, so that we are compelled to fall back on Dr. Steindachner's description for comparison. The differences between this species and S. trichocephalus are not very evident from the comparison of the descriptions, but as the two belong to different faunal regions it is probable that other differences would appear on eomparison of specimens.

\section{Sphæroides angusticeps.}

Tetrodon angusticeps Jenyns, Voyage of Beagle, Fishes, 154, 28, 1842 (Galapagos Is.), Günther, viii, 287, 1870 (copied); Jordan \& Gilbert, Proc. U. S. Nat. Mus., 1882, 631 (Panama); Jordan, Proe. U. S. Nat. Mus., 1885, 393 (Panama). Anchisomus angusticeps Richardson, Voyage of Herald, Fishes ; 1854, 159, (Galapagos).

Canthogaster lobatus Steindachner, Ichthyol. Notizen, x, 18, taf. 5, f. 3, 1870, (Altata: from a shriveled specimen.)

\section{Habitat.-Panama fauna; Altata to the Galapagos Islands.}

This strongly marked species was first described from large specimens in poor condition, with the spines obsolete, or lost. Next it was redescribed by Dr. Steindachner from a young example, shriveled in strong alcohol. Later two large examples (12 inches), one in the museum of Yale College, the other now in the National Museum, were examined by Professors Jordan and Gilbert. These authors observe:

"These specimens agree perfectly with Dr. Steindachner's Altata specimen (type of Canthogaster lobatus), but the nostrils are formed as in typical species of Tetrodon (= Spharoides), $i$. e., tubular with two lateral openings near the summit. Jenyns' description of $T$. angusticeps was evidently drawn from a specimen in poor condition. This would account for the alleged absence of prickles on the skin. In all other respects the description agrees with the specimens before us-the narrow, channel-like interorbital space, the minute, papilliform protuber- 
ances on the skin, and the pair of fleshy flaps behind the nape being conspicuous features of the species."

In some regards, this species resembles S. spengleri, of which it may be regarded as the Pacific Coast representative.

\section{Sphæroides spengleri.}

Tetrodon spengleri Bloch, Naturgeschichte der Fische, 1, 135, 1782, taf. 144 ("India"); Gmelin, Systema Naturæ, 1788, 1446 (copied); Walbaum, Artedi Piscium, 1792, 592 (copied); Bloch \& Schneider, Syst. Ichthyol., 1801, 504, Turton, Syst. Nat., 1806, 890 (copied); Cuvier, Règne Animal, Ed. ii, 1828 (name only); Günther, VIII, 285, 1870 (Madeiı, Lanzarote, Cape Verde Islands, West Africa, Santa Cruz, Cuba); Cope, Trans. Am. Phil. Soc., 1871, 479 (Saint Martins, New Providence, Tortugas); Poey, Enumeratio, 1875, 173 ; Goode \& Bean, Proc. U. S. Nat. Mus., 1882, 235 (name only) ; Jordan \& Gilbert, Synopsis Fish N. A., 1882, 861; Jordan; Cat. Fish N. Am., 1885, 141. Le Tetrodon spenglerien, Lacépède, Poissons, 1, 501, 1797 (copied). Crayracion spengleri Kner, Novara Fische, 410, 1867. (Rio Janeiro.) Chilichthys spengleri Goode, Bull. U. S. Nat. Mus., V, 22, 1876. (Bermudas.) Cirrisomus spengleri Jordan \& Gilbert, Proc. U. S. Nat. Mus., 1878, 366.

Cirrhisomus spengleri Swainson, Nat. Hist. Fishes, ete., Vol. ii, 328. 1839; Gill, Proc. U. S. Nat. Mus., 1884, 421 (name on7y).

Le Tetrodon Plumier, Lacépède, Hist. Nat., Poiss., 1, 504, 1797. (Martinique; on) a drawing by Plumier.)

Tetrodon plumieri Bloch \& Schneider,Syst. Ichthyol., 1801, 508. (After Lacépède. Le Sphéroüde tuberculé Lacépède, II, 1, 1798. (Martinique; on a drawing (front view) by Plumier.)

Spharoides tuberculatus Pillot, Edition of Lacépède, 1831, VI, 279 (copied).

Tetrodon marmoratus Ranzani, Nov. Comm. Ac. Sci. Inst., Bonon., IV, 72, pl. 10, f. 1,1840 (Brazil); Lowe, "Trans. Zool. Soc., ii, 193" (Madeira); Valenciennes " in Webb and Berthelot, Poiss., Îles Canaries, pl. 20, f. 2." (Canaries.)

Tetrodon turgidus Poey, Synopsis, 432, 1868 (Cuba); Poey, Enumeratio, 1875, 172 (not of Mitchill); Jordan \& Gilbert, Proc. U. S. Nat. Mus., 1882, 306. (Pensacola; Galveston.)

Tetrodon nephelus Goode \& Bean, Proc. U. S. Nat. Mus., 1882, 235 (Gulf of Mexico); Goode \& Bean, Proc. U. S. Nat. Mus., 1882, 412 (Indian River, Pensacola); Jordan \& Gilbert, Synopsis, Fish, N. Am., 1883, 965; Bean, Cat. Intern. Fish. Exhib., 1883, 43 (Key West, Fla.); Jordan, Bull. U. S. Fish Comm., 79 (Key West) ; Jordan, Proc. U. S. Nat. Mus., 1884, 146 (Key West); Jordan \& Swain, Proc. U. S. Nat. Mus., 1884, 234 (Cedar Key); Jordan, Cat. Fish. N. Am., 41, 1885.

Habitat.-West Indian Fauna. Coast of Texas and Western Florida to Brazil and West Africa.

This is the most common species of the genus about the Florida Keys and the Gulf Coast, and probably throughout the West Indies generally.

The very large series of specimens of this species, obtained by Dr. Jordan at Key West, shows remarkable variations in the development of the prickles on the skin. This indicates that the latter character must be used with great caution in the distinction of species in this group.

In Dr. Jordan's paper on the fishes of Key West (Proc. U. S, Nat. Mus., 
1884,147 ) is a full description of the coloration of Sphoroides spengleri, together with the following account of the variations in the prickles:

"Young examples have the back and belly covered with rather large, not close-set, stellate prickles, as described in the original account of Tetrodon nephelus. Of the larger specimens; some have prickles only on the back, others on the belly only, one or two only a small area behind the eyes near the median line, while a majority of the largest (as well as some of the smaller ones) are entirely smooth. There is no doubt that these specimens all belong to one species, and that this is the original Tetrodon nephelus of Goode and Bean. The loss of the prickles is probably to some extent dependent on age."

Half-grown examples usually correspond very closely to the current descriptions of $C$. spengleri, and there seems to be no doubt that the original Tetrodon spengleri of Bloch, was based on such specimens. Tetrodon plumieri is evidently the same and the "sphceroide tubercule" of Lacépède is founded on a front view of the same fish. Ranzani's description and figure of Tetrodon marmoratus, as Professor Goode has already stated, represents $S$. spengleri very weill.

This description of Lacépède was originally accompanied only by a French form of the name, but in a reprint of Lacépède, edited by Pillot in Paris, in 1831, the Latin form, Sphceroides tuberculatus is supplied.

\section{Sphæroides maculatus.}

Toad-fish Schöpf, "Beobacht. Gesellsch. Naturf. Freunde, viii, 189, 1788 (Rhode Island).

Tetrodon hispidus var. Walbaum, Artedi Piscium, 1792,594 (after Schöpf) (not of Linnæus).

Tetrodon hispidus var. maculatus Bloch \& Schneider, Syst. Ichth., 1801, 504 (after Schöpf).

Tetrodon turgidus Mitchill, Trans. Lit. \& Phil. Soc. 1, 473, pl. 6, f. 5, 1815 (New York); Cuvier, Règne Animal, Ed. ii, 1828 (name only). Storer, Rept. Fishes, Mass. 1839, 169 (Massachusetts); DeKay, New York Fauna, Fishes, 1842, 321, pl. 55, f. 178 (New York) ; Ayres, Bostou Journ. Nat. Hist. 1842, 285 (Brookhaven, Long Island); Baird, Ninth Smithsonian Rept., 1854,352 (Great Egg Harbor, N. J.); Storer, Synopsis Fish. N. A., 1846, 241 Bean, Proc. U. S. Nat. Mus., 1880, 76 (Wood's Holl, Noank, Conn., East shore of Va., Cohasset Narrows, Mass.); Jordan \& Gilbert, Proc. U. S. Nat. Mus. 1882, 619,(Charleston); Jordan \& Gilbert, Syn. Fish. N. A., 1883, 861, Jordan Cat. Fish. N. Am. 141, 1885.

Gastrophysus turgidus Gill, Cat. Fish, East Coast, 1861 (name only).

Cirrlisomus turgidus Jordan \& Gilbert, Proc. U. S. Nat. Mus., 1878, 366 (Beaufort); Goode \& Bean, Bull. Essex Inst., 1879, xi, 3 (Salem, Provincetown, Mass.); Goode, Proc. U. S. Nat. Mus., 1879, 109 (St. John's River, Florida).

Chilichthys turgidus Gill, Cat. Fish. East Coast N. A., 15, 1873 (name only).

Habitat.-Atlantic coast of United States; Cape Ann to Northern Florida.

This well-known species is common along our Atlantic coast, its range apparently not extending farther southward than the Carolinas. The numerous specimens before us are from Wood's Holl and Beaufort. On 
the specimens examined by us we find no variation in the development of the prickles, and we regard this species as more constant in this respect than are most of the tropical forms. This is the only species of Spharoides commonly found on coasts of temperate regions. Its strong resemblance to $S$. spengleri indicates the probability that it is a geographical variety of the latter, but we have seen no intermediate examples.

The name Tetrodon hispidus var. maculatus is based on the excellent description of Schöpf, and see no reason why it must not stand in place of the later name of turgidus.

\section{Sphæroides politus.}

Tetrodon politus Girard, U. S. Pac. R. R. Expl., 1859, 340 (San Diego, California); Günther, Fısh. Centr. Amer., 1869, 489 (San José de Nicaragua); Günther, viii, 281, 1870 (San José, California); Jordan \& Gilbert, Proc. U. S. Nat. Mus., 1881, 274 (Punta San Ygnacio, Gulf of California); Jordan \& Gilbert, l. c., 1880, 453 (San Diego, Cal.) ; Jordan \& Gilbert, l. c., 1882, 631 (Panama); Jordan \& Gilbert, Bull. U. S. Fish Comm., 1882, 108 (Mazatlan); Jordan \& Gilbert, Syn. Fish, N. Am., 1883, 860. Jordan, Proc. U. S. Nat. Mus., 1885, 392 (San Diego, Mazatlan); Jordan, Cat. Fish. N. Am., 140, 185. Rosa Smith, Fishes of San Diego (San Diego).

Habitat.-Pacific coast of Tropical America, San Diego to Panama. All the specimens thus far known of this species are of large size (about a foot in length). These differ from S. testudineus (annulatus) only, so far as we can see, in the absence of prickles. With the knowledge which we now have of the variations in this respect in S. spengleri, we see little reason to doubt that Sphcroides politus is simply the adult form of S. testudineus annulatus. However, till this matter is clearly proven, we may admit it as a doubtful species.

\section{Sphæroides testudineus.}

\section{a. Atlantic specimens (testudineus).}

Ostracion oblongus glaber Artedi, Species 21, Genera 60. Balk, Amøn. Acad., 1, $591,1749$.

Orbis lavis variegatûs (the Globe-fish) Catesby, Nat. Hist. Carol., 1743, pl. 28, ("Virginia").

Tetraodon testudineus Linnæus, Syst. Nat., Ed. X, 1758, 332 (based on Balk and Artedi ); Linuæus, Syst. Nat. Ed. xii, 1766, 410; Gmelin, Syst. Nat., 1788, 1446 (copied); Walbaum, Artedi Piscium, 1792, 590 (copied); Günther, viii, 282, 1870 (Jamaica, Dominica, St. Croix, Puerto Cabello, British Guiana, Bahia); Poey, Enumeratio, 1875, 172(Havana); Jordan \& Gilbert, Syn. Fishes. N. A., 1883, 861 (West Indies) : Bean, Cat. Intern. Fish. Exhib., 1883, 43, Indian River, Fla.); Gill, Proc. U. S. Nat. Mus., 188t, 421, Bean \& Dresel, Proc. U. S. Nat. Mus., 1834, 151 (Jamaica); Jordan, Proc. U. S. Nat. Mus., 1885, 372 (Panama); Jordan, Cat. Fish. N. Am., 1885, 140 (not of Bloch, who has used this name for an East Indian species).

Cirrosomus testudineus Jordan \& Gilbert, Proc. U. S. Nat. Mus., 1878, 366 (Beaufort, N. C.); Goode, Proc. U. S. Nat. Mus., 1879, 109 (Mouth of St. Johns, Fla).

Tetrodon punctatús Bloch \& Schneider, Syst. Ichth., 1801, 506 (Brazil) (description inaccurate?); Muiller \& Troschel “'in Schomburgk's British Guiana, 111, 641,” 1842 (Guiana). 
Tetrodon geometricus Bloch \& Schneider, Syst. Ichth., 1801, 508 (based on Catesby) Cuvier, Règne Animal, 11, 1828 (name only); Cope, Proc. Ac. Nat. Sci. Phila., 120, 1870 (Newport, Mexico, Panama).

Tetrodon ammocryptûs Gosse, Nat. Soj. Jamaica, 287, 1851 (Jamaica).

Anchisomus reticularis (Kaup), Richardson, Voyage Herald, 1854, 161, pl. 31 (not Tetrodon reticularis Bloch \& Schneider, which is Tetrodon testudineus of Bloch, not of Linnæus).

Tetrodon reticularis Cope, Trans. Am. Phil. Society, 1871, 479 (St. Martins).

Holacanthus leionothos Gronow, Syst. Nat., Ed. Gray, 1854, 24.

Tetraodon bajacu Castlenau, Anim. Amér. Snd, Poiss., 98, 1855, pl. 47, f. 3.

Tetrodon punctatus Poey, Syn. Pisc. Cab., 1868, 432 (Havana).

b. Pacific examples, var. annulatus.

Tetrodon annulutus Jenyns, Zoöl. Beagle, 1842, 153 (Galapagos Islands); Steindachner, Ich. Beitr., v. 23 (Mazatlan).

Tetrodon testudineus annulatus Jordan, Cat. Fish. N. Am., 1885, 141.

Anchisomus geometricus (Kanp), " Richardson, Voyage Herald, 156, 1854, pl. 30" (Galapagos).

Tetrodon geometricus Günther, Fish. Centr. Amer., 1868, 489 (Panama, Galapagos).

Tetrodon heraldi Günther, Cat. Fish. Brit. Mus., viii, 1870, 283 (Galapagos Islands, Panama).

Tetrodon testudineus Jordan \& Gilbert, Bull. U. S. F. C., 1882, 111 (Panama); Jordan \& Gilbert, Proc. U. S. Nat. Mus., 1882, 370 (Cape San Lucas); Jordan \& Gilbert, l. c., 381 (Panama).

Habitat.-Both coasts of Tropical America; var. testudineus, from Virginia to Bahia ; var. annulatus from Gulf of California to Galapagos Islands.

This species is common through the West Indies and it ranges occasionally northward, as far as the coast of Virginia. On the Pacific coast it seems to be equally common.

We have seen from either coast only young examples of this species ( 2 to 6 inches long) and all of these have the spines on the back and belly well developed. The adult form, as elsewhere stated, is probably the species called Spharoides politus.

We have been unable to distinguish Atlantic specimens (testudineus) from Pacific specimens (annulatus), but in deference to the opinion of Dr. Guinther, we have separated the synonymy into two series, and we have also indicated in the key the supposed differences of the two forms.

The extensive synonymy of this species needs no special remark. The name testudineus is the earliest given binomially by Linnæus to any Tetrodont, and its application to the present species has been unques. tioned since the error of Bloch and his copyists was corrected by Günther. Both Linnæus and Balk correctly deseribe the dark spots and the pale curved lines or "sutures" on the back.

\section{Sphæroides formosus.}

Tetrodon formosus Günther, Cat. Fish. Brit. Mus., viii, 183, 1870 ("South America").

Habitat.-("South America.")

This species is known to us only from the description of Dr, Gün. 
ther, based on a single specimen. This description agrees fairly well with S. testudineus in all respects except the color of the curved streaks on the back. These markings are said to be dark, while in all the examples of $S$. testudineus which we have seen they are paler than the ground color. Further comparison will probably show the absolute identity of testudineus, annulatus, politus, and formosus, but for the present, the last two may stand in our list as doubtful species.

\section{III.-TETRAODON.*}

Crayracion Klein, Missus, iii, 18, 1742 (includes all the Tetrodontido, Diodontidoe, etc.; the first species mentioned, "lavissimus," being Lagocephalus lagocephalus) (pre-Linnæan).

Tetraodon Hasselquist, “Iter Palestin., 1757, 400" (fahaka=lineatus L.) (pre-Linnæan).

Tetraodon Linuæus, Syst. Nat., Ed. x, 1758, 332 (in part; testudineus ; lineatus, lagocephalus, etc.).

Les Ovoüdes Lacépède, Hist. Nat. Poiss., 1, 256, 1797 (commersonien; names in French only).

Ovum Bloch and Schneider, Syst. Ichth., 1801,530 (commersoni; name preocenpied in mollnsks).

Tetrodon Swainson, Nat. Hist., Class'n Fishes, 1839, ii, 194, 328 (testudineus Bloch= reticularis; no Linnœan species included).

Arothron Miiller, Abhandl. Berl. Akad., 1839 (1841 ?) 25:, (testudinarius=reticularis, etc.).

Tetraodon Bibron, Revue de Zoologie, 1855, 279 (lineatus; patoca; dorso-unicolor Bibron MSS. ; bouronensis Bibr. MSS.).

Les Dilobomyctères (DILовомyстеr) Bibron, l. c. (reticularis; hispidus; maculatus; meleagris; nigropunctatus; mappa ; diadematus ; longicauda ; sordidus ; immaculatus).

Les Dichotomyctères (Dichotomycter) Bibron, l. c. (fluviatilis).

? Les Ephippions (Ephippion) Bibron, 1. c. (maculatum Bibron MSS.).

Brachycephalus Hollard, Etudes sur les Gymnodontes, 1857, 332 (includes Tetrao; don and Dichotomycter of Bibron, the former group being regarded as the type, no species mentioned, but the type therefore properly $T$. lineatus.

Crayracion Bleeker, Atlas Ind. Ichth., Gymnodontes, 1867 (immaculatus, etc.) (after Klein).

Tetrodon Gill, Proc. U.S. Nat. Mus., 1884, 421 (lineatus=fahaka).

\section{Type Tetraodon lineatus Linnæus.}

In the subdivision of the old genus Tetraodon, there is some doubt as to which of the several minor groups should retain the original name. We may therefore glance for a moment at the history of the group.

The name Tetraodon first appears as a generic term, so far as known to us, in Hasselquist's Travels in Palestine, edited by Linnæus, in 1757. We have not examined this work, but our impression is that it is binomial in form, and that the name Tetraodon is here associated only with

* This name, usually and preferably spelled Tetrodon, was originally given as Tetraodon by Linnæus. The latter form should therefore be used.

Proc. N. M. $86-16$

Detober 13, i 886. 
Tetraodon fahaka, the Tetraodon lineatus of the Systema Naturæ, and a member of the group called Arothron.

If this work of Hasselquist be taken in consideration, the name Tetraodon must be assigned to the present group.

But the conventional starting point of binomial nomenclature is later, and in the Systema Naturæ, Linnæus includes all the species of the present family known to him, in the genus Tetraodon.

We must then consider the later attempts at restriction of the group.

In 1839, Swainson made the first attempt at generic division.

Retaining the name Tetrodon for the bulk of the species (including our genera Sphoroides and Tetraodon), he separated from it Lagocephalus, Leiodon (or Leisomus), Cirrhisomus, and Canthigaster (or Psilonotus).

The first and last of these were well defined. The others, Leiodon (based on the absence of prickles) and Cirrhisomus (based on the presence of cirri), rest on characters of no systematic importance. Under the generic name of Tetrodon, four species are mentioned as types. Three of these belong to the Arothron group; the other is a Chelonodon. But none of them are Linnæan species, although one of them (testudineus Bloch, not L.) was supposed by Swainson to be such. If we regard, with Dr. Gill, this subdıvision to be properly a restriction of the Linnæan genus, the name Tetraodon would again be synonymous with Arothron. But it may be objected that the Tetrodon of Swainson contained no species known to Linnæus, and hence its composition annot be considered as a proper restriction. This objection seems to us a valid one.

The next subdivision seems to be that of Müller (1841), who retained the name of Tetrodon for none of his divisions.

Next (1855) we have the subdivision of Bibron.* By him the group was dirided into a large number of genera, part of them without definition and all of them with French names only. For one of his sections the name Tetraodon was retained. This group, as arranged by Bibron, included a single Linnæan species as type. This one, lineatus, is a nember of the group called by Miiller, Arothron. This seems to be the first proper restriction of Tetrodon, and, so far as we ean see, it must stand, making Tetraodon the equivalent of Arothron.

* We are indebted to Dr. E. J. Nolan, of Philadelphia, for the following list of the nominal genera of Bibron and their constituent species:

Promécocephales Bib. T. argentatus, Lac.; lunaris Sehn., spadiceus Richarỏs, lævigatus, Lin., lagocephalus Bloch, non Lin. (l'espèce décrite par ce deruier est un Rhyncote Bib.), inermis Schlegel ; (diagnosis given).

Stenometopes Bib. D. testudineus, Lin., Spengleri Bloch, Plumieri Lacép., marmoratus Lowe, angusticeps Jenyns, lævissimus Bib., Kieneri Bib., binummulatus Bib., Bernieri Bib., subflavus Bib., Pleei Bib. (no diagnosis).

Dilobomycière Bib. T. reticularis Schn., hispidus Bloch, maculatus Lacep., meleagris Lac., nigro-punctatus Schn., mappa Les., diadematus Rüpp., longicauda Bib., sordidus Rüpp., immaculatus Lacep., Rupelli Bib. (diagnosis given).

Tetraodon Bib. T. lineatus Lin., patoca Ham. (Buchanan), dorsounicolor Bib., Bourouensis Bib. (diagnosis given). 
Later, 1857, Hollard worked over the material of Bibron, and adopted -on skeletal characters only-an arrangement of genera, not unlike that given in the present paper. His genera are Xenopterus (not American), Rhynchotus (= Canthigaster), Batrachops (= Colomesus), Brachycephalus i=Tetraodon), Apsicephalus (= Sphoroides and Lagocephalus), Monotreta (not American).

Hollard supplies a Latin form to the French names of Bibron, and using the name Tetrodon as a general term, he places Bibron's Tetraodon as a subgenus under his own Brachycephalus.

In 1867, Bleeker, probably regarding lineatus as the proper type of Tetraodon, seems to have suppressed the latter name as a synonym of the name Crayracion used by Klein, before the date of the Systema Naturæ. Other ichthyologists do not give Klein's names precedence over those of Linnæus, and under the rules of nomenclature which we adopt, Crayracion must be disregarded.

In 1873, Professor Gill used the name Tetrodon as synonymous with Lagocephalus, and in 1885 as synonymous with Arothron. In 1883, Jordan and Gilbert regarded $T$. testudineus as its type, thus making it synonymous with Sphceroides.

It seems evident to us, from the above data, that it is best to regard Tetraodon lineatus as the type of Tetraodon, and thus to make the latter name the equivalent of Arothron.

The numerous species of Tetraodon belong chiefly to the East Indies, but one being known from American waters.

\section{ANALYSIS OF SPECIES OF TETRAODON.}

$a$. Entire body, except snout and caudal peduncle, thickly beset with long, robust quill-like spines, which are longest and most numerous on the belly. Snout short, cuboid; interorbital space wide, concave, its width greater than length of snout, and nearly twice diameter of eye; nasal tentacle bifid to the base, the inner surface of each division thickly covered with minute, cup-shaped depressions, the openings of the nostrils. Length of tentacle half its distance from eye and one-fourth diameter of eye. No cirri or dermal flaps or folds. D. 9, A. 10. Color dark brown, everywhere above with round white spots, most numerous on caudal peduncle, the largest half diameter of pupils; a dark area around base of pectorals, bounded by a white line. Several parallel longitudinal black streaks below pectorals. Size large (about 12 inches).

ERETHIZON, 11.

Amblyrhynchotus Bib. T. Honckenii Bloch, oblongus Bloch, Richei Fréminville, alboguttatus Bib. (diagnosis given).

Aphanacanthes Bib. T. reticulatus Bib. (no diagnosis).

Epipédorhynque Bib. T. Freycinetii Bib., Leschenaultii Bib., Gernærtii Bib. (no diagnosis).

Geneion Bib. 'T. (G.) maculatum Bib. (diagnosis given).

Catophorhynque Bib. C. lampris Bib., longispinis Bib. (diagnosis given).

Batrachops Bib. T. psittacus, Schn. (Ostracion tetraodon Seba) (diagnosis given).

Monotreta Bib. T. cutcutia Ham. (Buchanan) (diaguosis given).

Dichotomycter Bib. T. fluviatilis Ham. (Buchanan) (no diagnosis).

Ephippion Bib. E. maculatum Bib. (diagnosis given).

Xenopètres Bib. X. Belangerii Bib. (diagnosis given).

Rhynchotes Bib. T. Gronovii Cuv., margaritatus Rüpp., striolatus Quoy et Gaim., Peronii Bib., latero-fasciatus Bib. (diagnosis given). 


\section{Tetraodon erethizon.}

Arothron erethizon, Jordan \& Gilbert, Proc. U. S. Nat. Mus., 1882, 631 (Panama); Jordan, Proc. U. S. Nat. Mus., 1885, 393 (Panama).

\section{Habitut.-Panama fauna.}

Six large specimens of this species were taken by Prof. Frank H. Bradley at Panama. These are now in the museum of Yale College and in the U. S. National Museum.

Several others were obtained in 1883 by Professor Gilbert. These have been destroyed by fire. No young examples have been taken.

\section{IV.-COLOMESUS.}

. Les Batrachopes (Batrachops) Bibron, Révue Zoölogique, 1855, 279 (psittacus).

Batrachops Hollard, Etudes sur les Gymnodontes, 1857, 321 (psittacus); (name preoccupied).

Colomesus Gill, Proc. U. S. Nat. Mus., 1884, 422 ( psittacus).

Type Tetrodon psittacus Bloch \& Schneider.

Our knowledge of this genus rests wholly on the figure of its typical species given by Hollard. If this figure be correct, it represents a strongly marked type, considered by Professor Gill as forming a distinct subfamily (Colomesince). The single known species inhabits fresh waters.

ANALYSIS OF SPECIES OF COLOMESUS.

a. (Body covered with small, two-rooted spines, except on snout, around the pectoral fin and on caudal peduncle; some spires behind dorsal in very old examples. Spines on sides, with their points turned toward the back. Snout very obtuse, its length less than the width of the interorbital space, which is convex. Eye small, not one-third interorbital width. Brownish, with 6 dark eross-bands on the back, the two bands between dorsal and pectoral sometimes confluent.)

12. Colomesus psittacus.

Psittacus, 12.

Tetrodon psittacus Bloch \& Schneider, Syst. Ichth., 1801, 505, taf. 95 ("Malabar"); Günther, viii, 286, 1870. (Essequibo R., Surinam. Rio Capin, Pará.)

Cheilichthys psittacus Mïller \& Troschel, "Schomburgk's, British Guiana iii, 641 " (Surinam); Steindachner, "Verh. Zool,-Bot. Ges. Wien, 1861, taf. 4, f. 2."

Batrachops psittacus Hollard, Êtudes sur les Gymnodontes, 1857, 322.

Le Tetrodon perroquet Lacépède, 1, 217. (Copiє d.)

Cheilichthys asellus Müller \& Troschell, "Schomburgk Brit. Guiana, iii, 641." 1842. (Surinam.)

Habitat.-Rivers of Guiana and Brazil.

This species is known to ús only through the descriptions above cited. Among the American species, it seems to be the only one with fluviatile habit.

\section{V.-CANTHIGASTER.}

Canthigaster Swainson, Nat. Hist. Class'n Fishes, ii, 1839, 194 (diagnosis only; no species mentioned).

Psilonotus Swainson, Nat. Hist., Class'n Fishes, ii, 1839, 328 (rostratus : electricus) (preoccupied in Hymenoptera). 
Tropidichthys Bleeker, Nat. Tyds. Nederl., Ind., iv, 1854 (valentini.)

Avosmus Peters, Wiegmann's Archiv, 1855, 274 (tceniatus, etc.).

Les Rynchotes (Rhynchotus) Bibron, Revue de Zoologie, 1855, 279 ; (Gronovii; margaritatus, striolatus : peronii, laterofasciatus.)

Rhynchotus Hollard, Études sur les Gymnodontes, 1857, 320 (peroni.)

Anosmius Günther, Cat. Fishes, Brit. Mus., viii, 300, 1870 .

Canthigaster Bleeker, Atlas. Ichth. Gymn., 186\%, 80, etc.

P'silonotus Gill, Proc. U. S. Nat. Mus., 1884, 421 (rostratus.)

\section{Type Tetrodon rostratus Bloch.}

This genus is strongly marked as to its external characters, and still more peculiar as to its skeleton. Professor Gill has lately raised it to the rank of a separate family under the name of Psilonotida.

The proper name of the genus has been involved in some confusion, owing to the use by Swainson of two different names for it.

On page 194 of his miserable work on the classification of fishes, Swainson gives an analytical key to the genera, and applies to the present group the name of Canthigaster (correctly written Acanthogaster). No species are here mentioned by Swainson, but in this ease his diagnosis is accurate and sufficient. On page 328, these genera are again defined, the present one in nearly the same way, but uuder the name of Psilonotus. Two species (rostratus: electricus) are here mentioned as types.

Professor Gill has preferred to adopt the last-mentioned name, regarding Canthigaster as unidentifiable except through the medium of the species mentioned under the diagnosis of Psilonotus. Dr. Bleeker has preferred to take the earlier name of Canthigaster. In this case it is certainly true that no doubt could exist as to what Swainson intended to include under Canthigaster, even had the second diagnosis been omitted; moreover, the name Psilonotus is preoccupied. We see, therefore, no sufficient reasou for setting this name aside, objectionable as it is.

The species of Canthigaster are somewhat numerous and belong mostly to the East Indian fauna. As a rule, they are smaller in size than most of the other Tetrodonts.

\section{ANALYSIS OF SPECIES OF CANTHIGASTER.}

a. No black ocellus índer the dorsal fin.

b. Upper parts dark brownish, withont white spots; caudal fin with its upper and lower margins abruptly black; the middle of the fin pale, immaculate; an irregular brownish band or series of dots from pectoral to upper margin of caudal, continuous with the dark band on the latter, lower band of caudal continued on lower side of tail; adult specimens (alwass?) with chestnutcolored bands on the caudal peduncle and on the chin; dark streaks about eye; abdomen with very small, two-rooted spines; body otherwise smooth; snout moderately produced, rather more than twice the concave interorbital space; caudal fin slightly lunate; dorsal rays about $6 . . .$. . Rostratus, 13.

$b b$. Upper parts everywhere behind head covered with round whitish spots, not larger than the pupil, and separated from each other only by a network of the brown ground color; fins all unmarked, pale; spines on the belly and on the front part of back; snout produced, its upper profile slightly concave.

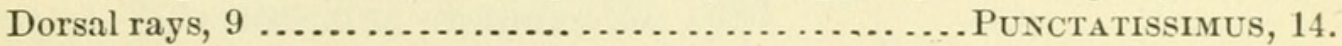




\section{Canthigaster rostratus.}

Tetrodon rostratus Bloch, Naturg. der Fische, 1, pl. 146, Abt., 1782 ("India"); Gmelin, Systema Naturæ, 1788, 1447 (copied); Walbaum, Artedi Piscium, 1792, 593 (copied); Bloch \& Schneider, Syst. Ichth, 1801, 505 (copied) ; Turton, Syst. Nat., 1806, 891 (copied).

Tetrodon rostratus Günther, viii, 303 (Madeira, Funchal, Porto Praya); Goode, Am. Journ. Sci. Arts., 1877, 290 (Bermuda); Günther, Shore Fishes Challenger, 9, 1880 (Bermuda).

Psilonotus rostratus Swainson, Nat. Hist. Fishes, etc., vol. ii, 328, 1839 (name only).

Canthigaster rostratus Jordan, Proc. U. S. Nat. Mus., 1886 (Pensacola).

Le Tetrodon Museau-Allongé Lacépède, Poissous, 1, 502, 1798 (copied).

Tetrodon capistratus Lowe, "Proc. Zool. Soc. London, 1839, 90 " (Madeira).

Psilonotus (or Anchisomus) caudacinctus Richardson, "Voyage Herald, 1854, 162, pl. 30, f. 1-3" (locality unknown).

Tetrodon caudacinctus Günther, viii, 303, 1870 (copied).

Canthogaster caudicinctus Cope, Trans. Am. Phil. Soc., 1871, 479 (St. Martin's). Tetrodon caudacinctus Poey, Enumeratio, 1875, 73 (Havana).

Tetrodon ornatus Poey, Synopsis Pisc. Cubens, 1868, 433 (Havana); Günther, viii, 303, 1870 (St. Croix.)

Habitat.-West Indian fauna. Pensacola to the Madeiras and Bermudas.

This species is known to us only from a single young specimen taken by Mr. Silas Stearns at Pensacola. This specimen agrees very closely with Dr. Günther's description of T. rostratus. It agrees also with the $T$. ornatus of Poey in all respects except that there are no chestnutcolored bars on the tail. According to Poey, however, these markings are wanting in the young. There is not much doubt, therefore, of the identity of T.ornatus and T. rostratus. The Tetrodon caudacinctus is not unlikely the same species, as Poey has supposed. Richardson's description does not apply so well to our specimen, however, as do those of the other authors mentioned.

Dr. Günther has identified this species with the Tetrodon rostratus of Bloch. Bloch's figure represents it very poorly. It is, however, evidently drawn from some species of Canthigaster, and there is no other one known so much like it as this. It must, however, be regarded as somewhat uncertain. If Bloch's name be set aside on this account, the present species may stand as Canthigaster capistratus.

\section{Canthigaster punctatissimus.}

Tetrodon punctatissimus Günther, Cat. Fish. Brit. Mus., VIII, 302, 1870 (Panama. "South America").

Psilonotus punctatissimus Jordan \& Gilbert, Proc. U. S. Nat. Mus., 1882, 370 (Cape San Lucas). Jordan, Cat. Fish. N. Am., 141, 1885 (name only).

Tetrodon oxyrhynchus Lockington, Proc. Acad Nat. Sci., Phil., 1881, 116 (Gulf of California).

Habitat.-Panama fauna. Gulf of California to Panama.

This species is known to us only from numerous specimens, the largest, three inches in length, collected by John Xantus, at Cape San Lucas. 


\section{RECAPITULATION.}

(W=West Indian fauna $; \mathrm{U}=$ East coast United States; $\mathrm{P}=$ Panama fauna $; \mathrm{C}=$ West coast United States.)

1. Lagocephalus Swainson.

1. Lagoccphalus Tavigatus Linnæus. U. W.

2 Sphrnoides Lacépède.

2. Sphceroides pachygaster Müller \& Troschel. W. (Species unknown to late writers.)

3. Sphcroides trichocephalus Cope. W. U. (Species imperfectly known.)

4. Spharoides fürthi Steindachner. P.

5. Spharoides angusticeps Jenyns. P.

6. Spharoides spengleri Bloch. W. U.

7. Spharoides maculatus Bloch \& Schneider. U.

8. Spharoides politus Girard. P. C. (Doubtful species; probably the adult form of $S$. testudineus.)

9. Spharoides testudineus Linnæus. W. P. U. (Possibly includes two species, testudineus (Atlantic) and annulatus (Pacific.)

10. Spharoides formosus Giinther. W. (Doubtful species; probably a form of $S$. testudineus. :

3. Tetraodon Linnæus.

11. Tetraodon erethizon Jordan \& Gilbert. P.

4. Colomesus Gill.

12. Colomesus psittacus Bloch. W.

5. Canthigaster Swainson.

13. Canthigaster rostratus Bloch. W. U. (Perhaps more than one species included in the synonymy.)

14. Canthigaster punctatissimus Günther. P.

\section{List of nominal species with idenitifications.}

[Tenable specific names are in italics.]

\begin{tabular}{|c|c|c|}
\hline Nominal species. & Date. & Identification. \\
\hline 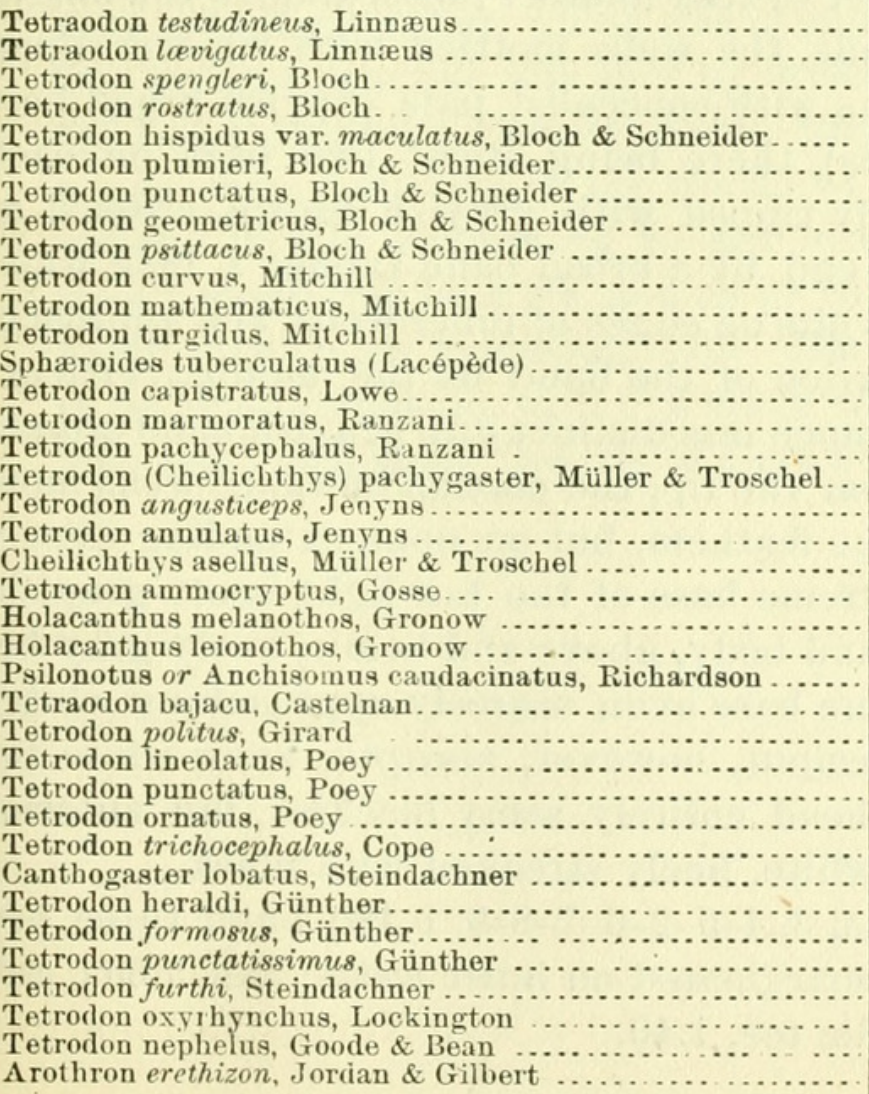 & $\begin{array}{l}1758 \\
1766 \\
1782 \\
1788 \\
1801 \\
1801 \\
1801 \\
1801 \\
1801 \\
1815 \\
1815 \\
1815 \\
1831 \\
1839 \\
1840 \\
1840 \\
1840 \\
1842 \\
1842 \\
1842 \\
1851 \\
1854 \\
1854 \\
1854 \\
1855 \\
1859 \\
1868 \\
1868 \\
1868 \\
1870 \\
1870 \\
1870 \\
1870 \\
1870 \\
1874 \\
1881 \\
1882 \\
1882\end{array}$ & $\begin{array}{l}\text { Sphæroides testudineus. } \\
\text { Lagocephalus lævigatus. } \\
\text { Sphæroides spengleri. } \\
\text { Canthigaster rostratus. } \\
\text { Sphær. maculatus. } \\
\text { Sphær. spengleri. } \\
\text { ? Sphær. testudineus. } \\
\text { Sphær. testudineus. } \\
\text { Colomesus psittaens. } \\
\text { Lagocephalus lævigatus. } \\
\text { Lagoc. lævigatus. } \\
\text { Sphær. maculatus. } \\
\text { Sphær. spengleri. } \\
\text { Canth. rostratus. } \\
\text { Sphær. spengleri. } \\
\text { Lagoc. lævigatus. } \\
\text { Sphær. pachygaster. } \\
\text { Sphær. augusticeps. } \\
\text { Sphær. testudineus (annulatns). } \\
\text { Colom. psittacus. } \\
\text { Sphær. testudineus. } \\
\text { Lagoc. lævigatus. } \\
\text { Sphær. testudineus. } \\
\text { Canth. rostratus. } \\
\text { Sphær. testudineus. } \\
\text { Sphær. (testudineus) politns. } \\
\text { Lagoc. lævigatus. } \\
\text { SpLær. testudineus. } \\
\text { Canth. rostratus. } \\
\text { Sphær. trichocephalus. } \\
\text { Sphær. angusticeps. } \\
\text { Sphær testudineus (annulatns). } \\
\text { Sphær. formosus. } \\
\text { Canth. punctatissimus. } \\
\text { Sphær. fürthi. } \\
\text { Canth. punctatissimus. } \\
\text { Sphær. spengleri. } \\
\text { Tetraodon erethizon. }\end{array}$ \\
\hline
\end{tabular}

INDIANA UNIVERSITY, January 25, 1886. 


\section{$2 \mathrm{BHL}$ Biodiversity Heritage Library}

Jordan, David Starr and Edwards, Charles Lincoln. 1886. "A review of the American species of Tetraodontidae." Proceedings of the United States National Museum 9(566), 230-247. https://doi.org/10.5479/si.00963801.9-566.230.

View This Item Online: https://www.biodiversitylibrary.org/item/32555

DOI: https://doi.org/10.5479/si.00963801.9-566.230

Permalink: https://www.biodiversitylibrary.org/partpdf/34340

\section{Holding Institution}

Smithsonian Libraries

\section{Sponsored by}

Smithsonian

\section{Copyright \& Reuse}

Copyright Status: NOT_IN_COPYRIGHT

This document was created from content at the Biodiversity Heritage Library, the world's largest open access digital library for biodiversity literature and archives. Visit BHL at https://www.biodiversitylibrary.org. 